\title{
New bactericide derived from Isatin for treating oilfield reinjection water
}

\author{
Gang Chen ${ }^{1}$, Hui-jun Su', Min Zhang ${ }^{1}$, Fang Huo', Jie Zhang ${ }^{1}$, Xiao-jiang Hao ${ }^{2 *}$ and Jing-rui Zhao ${ }^{3}$
}

\begin{abstract}
Isatin, an extract from Strobilanthes cusia (Nees) Kuntze, was the base for synthesizing derivatives that were screened for antibacterial activity against oilfield water-borne bacteria. The bacterial groups are sulfate reducing, iron and total. The derivatives were characterized by spectrums and they showed good to moderate activity against sulfate reducing bacteria.
\end{abstract}

\section{Background}

The roots and the leaves of the plant, Strobilanthes cusia (Nees) Kuntze of the Acanthaceae family that is widely distributed in northern and central China, have been used in traditional Chinese medicine to treat a variety of ailments caused by microorganisms and virus. It is suggested that the demonstrated use can be extended to processing oilfield water to remove or reduce bacteria before the water is re-injected into formations via wells.

The alkaloid isatin or indole-2-3-dione (Figure 1) is a compound found in Strobilanthes cusia (Nees) Kuntze and many other plants such as genus Isatis, Calanthe discolor LINDL, Couroupita guianensis Aubl. and in mammalian tissue [1]. It has versatile bioactivity [2] and it is used to synthesize a large variety of heterocyclic compounds in preparing drugs [3-7]. Isatin Schiff bases are reported to have antibacterial activity against Bacillus subtilis [8], Gram(+) and Gram(-) bacterial strains [9] and Magnaporthe grisea [10] among others. The compound has been produced industrially and can thus be used for large-scale applications such as treating oilfield water before re-injection.

\section{Base synthesis and identification}

\section{Synthesis of isatin derivatives}

Isatin $(1 \mathrm{mmol})$ was dissolved in methanol $(20 \mathrm{ml})$ and a methanol solution of $1.2 \mathrm{mmol}$ amino compound $(10 \mathrm{ml})$ was added dropwise, until the disappearance of

\footnotetext{
* Correspondence: haoxj@mail.kib.ac.cn

${ }^{2}$ State Key Laboratory of Phytochemistry and Plant Resources in West China, Kunming Institute of Botany, Chinese Academy of Sciences, Kunming 650204, People's Republic of China

Full list of author information is available at the end of the article
}

isatin, as evidenced by thin-layer chromatography. The solvent was removed in vacuo and the residue was separated by column chromatography (silica gel, petroleum ether/ ethyl acetate $=1: 1 \sim 1: 3 \mathrm{v} / \mathrm{v})$, to give the product. Single crystals of the compound 4 suitable for X-ray analysis was obtained on slow evaporation of a methanol solution $(30 \mathrm{ml})$ of the product $(30 \mathrm{mg})$ over a period of $7 \mathrm{~d}$.

\section{$\mathrm{X}$-ray data collection and structure refinement}

Intensity data for colorless crystals of compound 4 was collected at $150 \mathrm{~K}$ on a Bruker SMART $1000 \mathrm{CCD}$ fitted with Mo Ka radiation. The data sets were corrected for absorption based on multiple scans [11] and reduced using standard methods [12]. The structures was solved by direct-methods [13] and refined by a full-matrix leastsquares procedure on $\mathrm{F}^{2}$ with anisotropic displacement parameters for non-hydrogen atoms, carbon-and nitrogen bound hydrogen atoms in their calculated positions and a weighting scheme of the form $w=1 /\left[\sigma^{2}\left(F_{\mathrm{o}}^{2}\right)\right.$ $\left.+(\alpha P)^{2}+b P\right]$ where $\left.P=\left(F_{\mathrm{o}}^{2}+2 F_{\mathrm{c}}^{2}\right) / 3\right)[14]$. Crystal data and refinement details were given in Table 1.

\section{Microbiological monitoring}

Viable counts of SRB, TGB and FB were determined with the "most probable number" method, People's Republic of China Standard of Petroleum and Natural Gas Industry, the national method of the bactericidal agent's performance, SY/T 5890-1993). The produced water containing the three kinds of bacteria was gathered from Zichang Oilfield Factory, Yanchang Oilfield. 


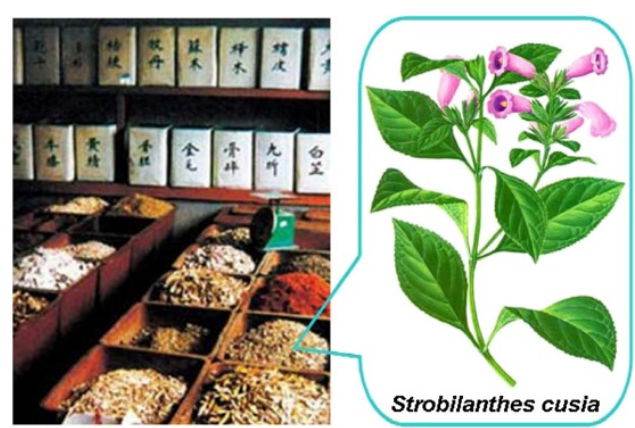<smiles>[R]N=C1C(=O)Nc2ccc([R])cc21</smiles>

Traditional Chinese Medicinal Herbs

Pharmacological Compounds

Figure 1 Development of new bactericide for oilfield reinjection water treatment from traditional Chinese medicine.

Table 1 Experimental data of compound A and B

\begin{tabular}{|c|c|}
\hline Empirical formula & $\mathrm{C}_{8} \mathrm{H}_{6} \mathrm{~N}_{2} \mathrm{O}_{2}$ \\
\hline Formula weight & 162.15 \\
\hline Temperature & $293(2)$ \\
\hline Wavelength $\left(\mathrm{Mo} \mathrm{K}_{\mathrm{a}}\right)$ & 0.71073 \\
\hline Crystal system & Monoclinic \\
\hline Space group & $P 2(1)$ \\
\hline \multicolumn{2}{|l|}{ Crystal data } \\
\hline $\mathrm{a}(\hat{A})$ & $3.8800(6)$ \\
\hline$b(\AA)$ & 10.180(9) \\
\hline$c(\hat{A})$ & $9.0500(6)$ \\
\hline$a\left({ }^{\circ}\right)$ & 90.00 \\
\hline$\beta\left({ }^{\circ}\right)$ & 93.90(3) \\
\hline$Y\left({ }^{\circ}\right)$ & 90.00 \\
\hline Volume & $356.63(12)$ \\
\hline Z & 2 \\
\hline Density $\left(\mathrm{mg} / \mathrm{m}^{3}\right)$ & 1.510 \\
\hline Absorption coefficient & 0.112 \\
\hline$F(000)$ & 168 \\
\hline Crystal size & $0.20 \times 0.22 \times 0.30 \mathrm{~mm}^{3}$ \\
\hline Theta range for data collection $\left(^{\circ}\right)$ & 1.9 to 27.3 \\
\hline Index ranges & $-4 \leq h \leq 5 ;-13 \leq k \leq 12 ;-11 \leq \mathrm{I} \leq 12$ \\
\hline Reflections collected & 3112 \\
\hline Independent reflections & 2190 \\
\hline Reflections theta $\left(^{\circ}\right)$ & 2.26 to 28.27 \\
\hline Absorption correction transmission & 0.9440 to 0.9861 \\
\hline Reflections with $1 \geq 2 \sigma(l)$ & 1427 \\
\hline Number of parameters & 109 \\
\hline Goodness-of-fit on $F^{2}$ & 1.006 \\
\hline Final R indices $[l>2 s(l)]$ & $\mathrm{R} 1=0.1884 ; \mathrm{wR} 2=0.1323$ \\
\hline $\mathrm{R}$ indices (all data) & $\mathrm{R} 1=0.0674 ; \mathrm{wR} 2=0.1027$ \\
\hline Refine different density & -0.224 to 0.176 \\
\hline
\end{tabular}

\section{Results and discussion}

\section{Chemistry}

The isatin derivatives were synthesized as shown in Scheme 1. All the isatin derivatives were characterized by ${ }^{1} \mathrm{H}-\mathrm{NMR}(400 \mathrm{MHz})$ and MS (EI) spectra and the results were summarized in Table 2 . The entire spectra consist with the anticipated structures.

Besides, single crystal of compound 4 was analysized by $\mathrm{X}$-ray, which confirms the assignment of the structure from spectroscopic data. The values of the geometric parameters of compound 4 are within normal ranges and experimental errors. The X-ray structural analysis confirmed the assignment of its structure from spectroscopic data. The molecular structure is depicted in Figure 2, and a packing diagram of compound 4 is depicted in Figure 3. Geometric parameters of compound 4 are in the usual ranges. The indol-2-one ring system is substantially planar. In the crystal structure, intermolecular $\mathrm{N}-\mathrm{H}-\mathrm{N}$ and $\mathrm{O}-\mathrm{H}-\mathrm{O}$ hydrogen bonds (Table 3 ) are effective in the stabilization of the structure and are responsible for the formation of a one-dimensional network. The angle of $\mathrm{C} 1-\mathrm{C} 2-\mathrm{N} 2$ is $115.734^{\circ}$, and the angle of $\mathrm{C} 2-\mathrm{N} 2-\mathrm{O} 2$ is $112.199^{\circ}$.

\section{Bioactivity}

Produced water is a consequence of an oilfield exploitation that uses waterflood or steam injection or has an aquifer linked to the reservoir. The most usual disposal ways for high volumes of produced water is re-injected after treatment, which will meet some requirements<smiles>[R]N=C1C(=O)Nc2ccc([R])cc21</smiles>

Scheme 1 Synthesis of isatin derivatives by condensation reaction. 
no.<smiles>O=C1Nc2ccccc2C1=O</smiles>

2<smiles>Cc1ccc2c(c1)C(=O)C(=O)N2</smiles>

3<smiles>O=C1Nc2ccc([N+](=O)[O-])cc2C1=O</smiles>

4<smiles>O=C1Nc2ccccc2/C1=N/O</smiles>

5<smiles>NC(=O)NN=C1C(=O)Nc2ccccc21</smiles>

6<smiles>NC(=S)NN=C1C(=O)Nc2ccccc21</smiles>

7<smiles>Cc1ccc2c(c1)C(=NNC(N)=O)C(=O)N2</smiles>

8<smiles>O=C1Nc2ccccc2/C1=N/c1ccc(O)cc1</smiles>

${ }^{1} \mathrm{H}-\mathrm{NMR}\left(\mathrm{D}_{6}\right.$-Acetone), $\delta: 8.05(1 \mathrm{H}, \mathrm{d}, J=7.2 \mathrm{~Hz}), 7.36(1 \mathrm{H}, \mathrm{t}, J=7.6 \mathrm{~Hz}), 7.04(1 \mathrm{H}, \mathrm{t}, J=7.6 \mathrm{~Hz}), 6.95(1 \mathrm{H}, \mathrm{d}$, $J=7.6 \mathrm{~Hz}), 6.84(1 \mathrm{H}, \mathrm{d}, J=7.6 \mathrm{~Hz}) ; \mathrm{MS} \mathrm{m} / \mathrm{z}: 162\left(\mathrm{M}^{+}\right)$

${ }^{1} \mathrm{H}-\mathrm{NMR}\left(\mathrm{D}_{6}\right.$-DMSO), $\delta: 12.40(1 \mathrm{H}, \mathrm{s}), 11.08(1 \mathrm{H}, \mathrm{s}), 9.06(1 \mathrm{H}, \mathrm{s}), 8.95(1 \mathrm{H}, \mathrm{s}), 7.66(1 \mathrm{H}, \mathrm{d}, J=7.6 \mathrm{~Hz}), 7.30(1 \mathrm{H}$, $\mathrm{t}, J=7.6), 7.10(1 \mathrm{H}, \mathrm{t}, J=7.6 \mathrm{~Hz}), 6.90(1 \mathrm{H}, \mathrm{d}, J=8.0 \mathrm{~Hz}) ; \mathrm{MS} \mathrm{m} / \mathrm{z}: 204\left(\mathrm{M}^{+}\right)$

${ }^{1} \mathrm{H}-\mathrm{NMR}\left(\mathrm{D}_{6}\right.$-DMSO), $\delta: 12.46(1 \mathrm{H}, \mathrm{s}), 11.02(1 \mathrm{H}, \mathrm{s}), 9.05(1 \mathrm{H}, \mathrm{s}), 8.96(1 \mathrm{H}, \mathrm{s}), 7.64(1 \mathrm{H}, \mathrm{d}, J=7.6 \mathrm{~Hz}), 7.34(1 \mathrm{H}$, $\mathrm{t}, J=7.6), 7.08(1 \mathrm{H}, \mathrm{t}, J=7.6 \mathrm{~Hz}), 6.91(1 \mathrm{H}, \mathrm{d}, J=8.0 \mathrm{~Hz}) ; \mathrm{MS} m / z: 220\left(\mathrm{M}^{+}\right)$

${ }^{1} \mathrm{H}-\mathrm{NMR}\left(\mathrm{D}_{6}\right.$-DMSO), $\delta: 12.01(1 \mathrm{H}, \mathrm{s}), 11.01(1 \mathrm{H}, \mathrm{s}), 9.23(1 \mathrm{H}, \mathrm{s}), 8.90(1 \mathrm{H}, \mathrm{s}), 7.54(1 \mathrm{H}, \mathrm{d}, J=7.6 \mathrm{~Hz}), 7.30(1 \mathrm{H}$, $\mathrm{t}, J=7.6), 6.86(1 \mathrm{H}, \mathrm{d}, J=8.0 \mathrm{~Hz}), 2.48(1 \mathrm{H}, \mathrm{s}) ; \mathrm{MS} \mathrm{m} / \mathrm{z}: 218\left(\mathrm{M}^{+}\right)$

${ }^{1} \mathrm{H}-\mathrm{NMMR}\left(\mathrm{D}_{6}\right.$-DMSO), $\delta: 10.92(1 \mathrm{H}, \mathrm{s}), 9.56(1 \mathrm{H}, \mathrm{s}), 7.32(2 \mathrm{H}, \mathrm{m}), 6.86(4 \mathrm{H}, \mathrm{m}), 6.74(3 \mathrm{H}, \mathrm{m}) ; \mathrm{MS} \mathrm{m} / \mathrm{z}: 238\left(\mathrm{M}^{+}\right)$

9

${ }^{1} \mathrm{H}-\mathrm{NMR}\left(\mathrm{CDCl}_{3}\right), \delta: 9.14(1 \mathrm{H}, \mathrm{s}), 7.32(1 \mathrm{H}, \mathrm{d}, J=7.2 \mathrm{~Hz}), 7.08(2 \mathrm{H}, \mathrm{d}, J=8.8 \mathrm{~Hz}), 6.99(3 \mathrm{H}, \mathrm{m}), 6.93(1 \mathrm{H}, \mathrm{d}$,<smiles>O=C1Nc2ccccc2/C1=N/c1ccccc1</smiles>
$\left.\mathrm{OCH}_{3} J=8.0 \mathrm{~Hz}\right), 6.79(1 \mathrm{H}, \mathrm{t}, J=7.6 \mathrm{~Hz}), 3.88(3 \mathrm{H}, \mathrm{s}) ; \mathrm{MS} \mathrm{m} / \mathrm{z}: 253\left(\mathrm{M}^{+}\right)$

10<smiles>O=C1Nc2ccccc2/C1=N/c1ccc(Cl)cc1</smiles>

${ }^{1} \mathrm{H}-\mathrm{NMR}\left(\mathrm{CDCl}_{3}\right), \delta: 9.98(1 \mathrm{H}, \mathrm{s}), 7.64(1 \mathrm{H}, \mathrm{d}, J=7.2 \mathrm{~Hz}), 7.42(1 \mathrm{H}, \mathrm{d}, J=7.2 \mathrm{~Hz}), 7.14(2 \mathrm{H}, \mathrm{d}, J=8.8 \mathrm{~Hz}), 7.02$ $(3 \mathrm{H}, \mathrm{m}), 6.81(1 \mathrm{H}, \mathrm{d}, J=8.0 \mathrm{~Hz}) ; \mathrm{MS} \mathrm{m} / \mathrm{z}: 256\left(\mathrm{M}^{+}\right)$ 


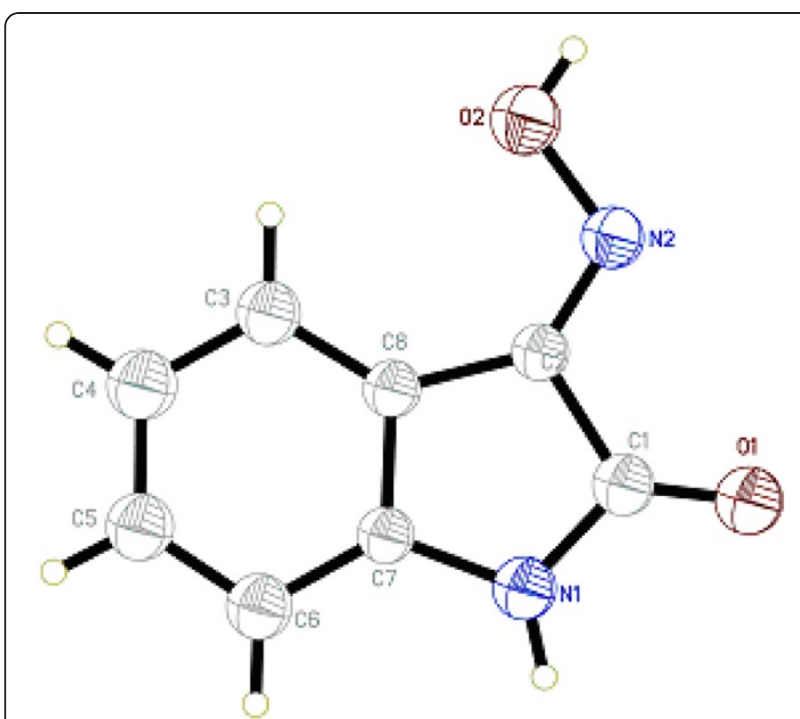

Figure 2 An ORTEP-3 drawing of compound 4, with the atomnumbering scheme and $30 \%$ probability displacement ellipsoids.

imposed by environmental regulations [15]. Microbiologically influenced corrosion (MIC) caused by growth of sulfate reducing bacteria (SRB), iron bacteria (IB) and total general bacteria (TGB) in oil pipelines, is considered a major problem for water treatment in the oil industry [16]. MIC can result in different types of attack: pitting, crevices, dealloying and erosion in pipelines [17]. Corrosion products produced by microorganisms are production of hydrogen sulfide, molecular hydrogen, hydrogen ions and destabilization of metal oxide films. In addition, microbial degradation of crude oil can lead to increased acidity in the oil phase, and oil containing acids is a problem concerning corrosion of pipelines.

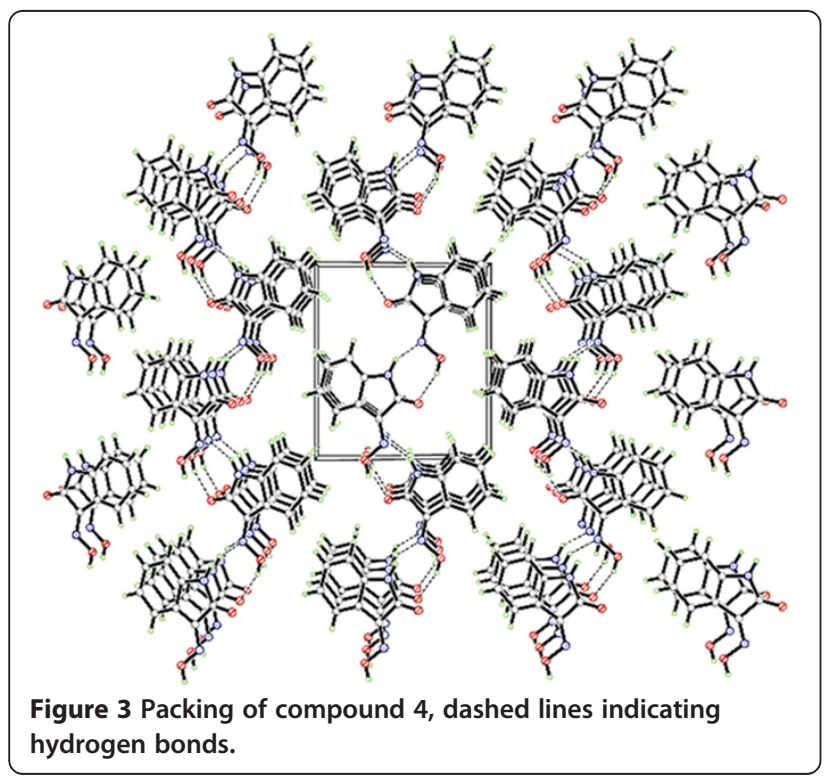

Table 3 Hydrogen-bond geometry in the crystal of compound $4\left(\AA^{\circ},{ }^{\circ}\right)$

\begin{tabular}{|c|c|c|c|c|}
\hline$\overline{D-H} \cdots A$ & $\mathrm{D}-\mathrm{H}$ & $\mathrm{H} \cdots \mathrm{A}$ & $D \cdots A$ & $\mathrm{D}-\mathrm{H} \cdots \mathrm{A}$ \\
\hline$\overline{\mathrm{N} 1-\mathrm{H} 1 \mathrm{~A} \cdots \mathrm{N} 2 \mathrm{i}}$ & $0 c x \times .86$ & 2.10 & $2.831(8)$ & 142 \\
\hline $\mathrm{O} 2-\mathrm{H} 2 \mathrm{~A} \cdots \mathrm{O} 1 \mathrm{ii}$ & 0.82 & 1.92 & $2.698(5)$ & 159 \\
\hline
\end{tabular}

The reported results showed that the interaction of IB, SRB and TGB accelerated the corrosion rate, and the corrosion in the mixture of IB, SRB and TGB was more serious than in a single microbial system. If this is the case, different treatment system to inhibit corrosion should be considered, among which bactericide agent has received the greatest acceptance. Currently, oxidizer, aldehyde, quatemary ammonium salt and heterocycle compounds has been used as bactericide agents, and $\mathrm{Cl}_{2}, \mathrm{ClO}_{2}$, formaldehyde, pentane-1, 5-dial, trichloroisocyanuric acid (TCCA) and ect [18], but the toxicity tests have been conducted on a limited selection.

In this work, isatin and amino compounds condensed to form the new $\mathrm{C}=\mathrm{N}$ bond, and it is the isostere of $\mathrm{C}=\mathrm{O}$ in the structure of isatin, which may ensure the bioactivity of these derivatives similar to isatin. The antifungal activity of these compounds against oilfield

\section{Table 4 The antifungal activity of isatin derivatives} against MIC

\begin{tabular}{|c|c|c|c|c|}
\hline \multirow[t]{2}{*}{ Compound } & \multirow[t]{2}{*}{ Concentration } & \multicolumn{3}{|c|}{ Microbiotic concentration $/ \mathrm{mL}$} \\
\hline & & SIB & IB & TGB \\
\hline- & - & 110.0 & 110.0 & 110.0 \\
\hline \multirow[t]{2}{*}{1} & $0.20 \mathrm{~g} / \mathrm{L}$ & 2.5 & 25.0 & 70.0 \\
\hline & $0.02 \mathrm{~g} / \mathrm{L}$ & 2.5 & 25.0 & 110.0 \\
\hline \multirow[t]{2}{*}{2} & $0.20 \mathrm{~g} / \mathrm{L}$ & 0.9 & 6.0 & 70.0 \\
\hline & $0.02 \mathrm{~g} / \mathrm{L}$ & 0.9 & 2.0 & 110.0 \\
\hline \multirow[t]{2}{*}{3} & $0.20 \mathrm{~g} / \mathrm{L}$ & 0.5 & 2.5 & 13.0 \\
\hline & $0.02 \mathrm{~g} / \mathrm{L}$ & 0.6 & 2.0 & 110.0 \\
\hline \multirow[t]{2}{*}{4} & $0.20 \mathrm{~g} / \mathrm{L}$ & 0.6 & 13.0 & 13.0 \\
\hline & $0.02 \mathrm{~g} / \mathrm{L}$ & 0.0 & 70.0 & 70.0 \\
\hline \multirow[t]{2}{*}{5} & $0.20 \mathrm{~g} / \mathrm{L}$ & 0.6 & 110.0 & 110.0 \\
\hline & $0.02 \mathrm{~g} / \mathrm{L}$ & 0.0 & 110.0 & 110.0 \\
\hline \multirow[t]{2}{*}{6} & $0.20 \mathrm{~g} / \mathrm{L}$ & 0.5 & 25.0 & 110.0 \\
\hline & $0.02 \mathrm{~g} / \mathrm{L}$ & 0.9 & 25.0 & 110.0 \\
\hline \multirow[t]{2}{*}{7} & $0.20 \mathrm{~g} / \mathrm{L}$ & 0.0 & 25.0 & 2.5 \\
\hline & $0.02 \mathrm{~g} / \mathrm{L}$ & 0.6 & 25.0 & 2.5 \\
\hline \multirow[t]{2}{*}{8} & $0.20 \mathrm{~g} / \mathrm{L}$ & 0.0 & 110.0 & 70.0 \\
\hline & $0.02 \mathrm{~g} / \mathrm{L}$ & 0.0 & 110.0 & 110.0 \\
\hline \multirow[t]{2}{*}{9} & $0.20 \mathrm{~g} / \mathrm{L}$ & 0.0 & 6.0 & 110.0 \\
\hline & $0.02 \mathrm{~g} / \mathrm{L}$ & 0.0 & 13.0 & 110.0 \\
\hline \multirow[t]{2}{*}{10} & $0.20 \mathrm{~g} / \mathrm{L}$ & 0.0 & 0.5 & 13.0 \\
\hline & $0.02 \mathrm{~g} / \mathrm{L}$ & 0.6 & 0.9 & 110.0 \\
\hline
\end{tabular}


microorganism was tested under the concentration of $0.20 \mathrm{~g} / \mathrm{L}$ and $0.02 \mathrm{~g} / \mathrm{L}$, and the results were summarized in Table 4.

From the table, it can be found that isatin is antifungal active against SRB, but inactive against IB and TGB under both concentrations. For the 5-substitued isatin, compound 2 and 3, the antifungal active against SRB is similar to isatin, slightly more potent against IB, but both, as well as isatin, are inactive against TGB. From the results of the 3-imine indole-2-one (compound 4-10), it was found that the SRB inhibitions are more effective potent under both concentration. While only compound 10 is active against IB with the microbial concentration of $0.5 / \mathrm{mL}$ under the concentration of $0.20 \mathrm{~g} / \mathrm{L}$ and $0.9 / \mathrm{mL}$ under the concentration of $0.02 \mathrm{~g} / \mathrm{L}$. Only compound 7 is active against TGB with the microbial concentration of $2.5 / \mathrm{mL}$ under both concentration.

\section{Competing interests}

The authors declare that they have no competing interests.

\section{Authors' contributions}

GC has conceived the study, formulated the research idea and prepared the manuscript draft version, HS, MZ and FH carried out the chemical synthesis, $\mathrm{JZ}$ carried out the Microbiological monitoring, and XH and JZ participated in its design and coordination. All authors have read and approved the final manuscript.

\section{Author details}

${ }^{1}$ College of Chemistry and Chemical Engineering, Xi'an Shiyou University, Xi'an 710065, People's Republic of China. ${ }^{2}$ State Key Laboratory of Phytochemistry and Plant Resources in West China, Kunming Institute of Botany, Chinese Academy of Sciences, Kunming 650204, People's Republic of China. ${ }^{3}$ Shannxi Hai'an Industry Co., LTD, Xi'an 710065, People's Republic of China.

Received: 21 May 2012 Accepted: 13 August 2012

Published: 28 August 2012

\section{References}

1. Yoshikawa M, Murakami T, Kishi A, Sakurama T, Matsuda H, Nomura M, Matsuda H, Kubo M: Novel indole S, O-bisdesmoside, calanthoside, the precursor glycoside of tryptanthrin, indirubin, and isatin, with increasing skin blood flow promoting effects, from two Calanthe species (Orchidaceae). Chem Pharm Bull 1998, 46(5):886-888.

2. Chen G, Hao XJ: Recent studies on the bioactivities of isatin. Natural Product Research and Development 2010, 22:356-360.

3. Chen G, Hao XJ, Sun QY, Ding J: Rapid eco-friendly synthesis and bioactivities of 3-nitromethylene-1,3-dihydro-indol-2-one analogues. Chemical Papers 2010, 64(5):673-377.

4. Chen G, He HP, Ding J, Hao XJ: Synthesis and antitumor activity evaluation of regioselective spiro [pyrrolidine-2, 3'-oxindole] compounds. Heterocyclic Communication 2009, 15(5):355-361.

5. Chen G, Yang J, Gao S, He HP, Li SL, Di YT, Chang Y, Lu Y, Hao XJ: Spiro [pyrrolidine-2,3'-oxindole] derivatives synthesized by novel regionselective 1,3-dipolar cycloadditions. Mol Divers 2012, 16:151-156.

6. Chen G, Zhang J, Tang Y, Hao XJ, Mu SZ: Micheal addition between isatin and acrylate derivatives. Letters in Organic Chemistry 2011, 8(9):614-617.

7. DaSilva JFM, Garden SJ, da C Pinto A: The chemistry of isatins: a review from 1975 to 1999. The Journal of the Brazilian Chemical Society 2001, 12:273-324.

8. Cerchiaro G, Aquilano K, Filomeni G, Rotilio G, Ciriolo MR, Ferreira AMDC: Isatin-schiff base copper(II) complexes and their influence on cellular viability. J Inorg Biochem 2005, 99:1433-1440.
9. Sridhara SK, Saravanana M, Ramesh A: Synthesis and antibacterial screening of hydrazones, Schiff and Mannich bases of isatin derivatives. Eur J Med Chem 2001, 36:615-625.

10. Chen G, Wang Y, He HP, Li SL, Zhou LG, Hao XJ: Synthesis of 3-imine/ methylene-indole-2-one compounds and the bioactivty screen on inhibition of germination of Magnaporthe grisea spores. Acta Botanica Yunnanica 2007, 29(6):712-721.

11. Sheldrick GM: SADABS. Germany: University of Göttingen; 2003. Version 2.10.

12. Otwinowski Z, Minor W: Methods in enzymology, vol276. In Macromolecular crystallography. Edited by Part A, Carter CW Jr, Sweet RM New York: Academic Press; 1997.

13. Sheldrick GM: SHELXL97. Germany: University of Göttingen; 1997.

14. Sheldrick GM: SHELXS97. Germany: University of Göttingen; 1997

15. Carlson $V$, Bennett EO, Rowe JA: Microbial flora in a number of oilfield water-injection system. SPE 1961, 1553-G.

16. Kajiyama F, Okamura K: Evaluating cathodic protection reliability on steel pipe in microbially active soils. Corrosion 1999, 55(1):74-80.

17. Rupi P: Assessment and control of mic in the oil industry in the $20^{\text {th }}$ century. Corrosion 2000, 00390.

18. Liu HT, Huang L, Li T, Gu YL: Application and progress in bactericide of sulfate reducing bacteria. Journal of Chinese Society for Corrosion and Protection 2009, 29(2):154-160.

doi:10.1186/1752-153X-6-90

Cite this article as: Chen et al:: New bactericide derived from Isatin for treating oilfield reinjection water. Chemistry Central Journal 2012 6:90.

Publish with ChemistryCentral and every
scientist can read your work free of charge
"Open access provides opportunities to our
colleagues in other parts of the globe, by allowing
anyone to view the content free of charge."
W. Jeffery Hurst, The Hershey Company.
- available free of charge to the entire scientific community
- peer reviewed and published immediately upon acceptance
- cited in PubMed and archived on PubMed Central
- yours - you keep the copyright
submit your manuscript here:
http://www.chemistrycentral.com/manuscript/

